\title{
Non-Standard Securitizations: Their Economic and Financial Applications Potential
}

\author{
Lucas Bernard $^{1}$, Willi Semmler ${ }^{2}$, Jason N. Schron ${ }^{3}$ \\ ${ }^{1}$ Department of Business, the City University of New York, College of Technology, New York, USA \\ ${ }^{2}$ Department of Economics, the New School for Social Research, New York, USA \\ ${ }^{3}$ Independent Researcher, USA \\ E-mail:LBernard@citytech.cuny.edu,SemmlerW@newschool.edu,vze23bcv@verizon.net \\ Received December 10, 2010; revised January 26, 2011; accepted February 6, 2011
}

\begin{abstract}
There are numerous obstacles that prevent non-uniform securitization products from being traded in different domestic and international marketplaces. Future-flow receivables and diversified payment rights are the most commonly used and traded assets in these markets. Remittances play an important role in generating funds in economically challenged countries. Securitization is also a major player in commodities markets and has causations and correlations to the current [domestic and international] economic recession. The securitization process for non-uniform products also has similarities to the sub-prime home loan crisis. Our current research explores the various ways in which the securitization process impacts commodity markets and prices. We are also interested in explaining the risks and regulations that prevent non-uniform securitizations from becoming standardized. In this short report, we outline some of the issues in this field.
\end{abstract}

Keywords: Secuitization, Commodities, Financialization

\section{Introduction}

There are many microeconomic, macroeconomic, legal, and other issues that prevent non-uniform securitization products from becoming uniform so that they can be traded in national and international marketplaces. Futureflow securitizations and diversified payment rights securitizations are two examples of non-uniform securitizations that have been under much scrutiny. Different countries have different types of non-uniform securitizations, e.g. Crude [1], and their different potential risks, constraints, perceived value, fiscal policies, market size, and trends in different marketplaces make it difficult to make these securitizations standard.

Non-uniform securitizations were first known as "asset-backed securitizations" in the early 1990s. They became known as "non-uniform securitizations" as their popularity grew globally and their restrictions and parameters begin to vary. Two examples of future-flow securetizations that are quite popular are future-flow securitizations and diversified payment rights (DPRs).

Future-flow securitizations became popular because they were readily accessible for developing countries seeking to obtain low-cost, long-term loans. Reputable pub- lic and private sector entities in these developing countries were able to raise funds in formerly hard-to-reach capital markets and obtain higher credit ratings than their own governments. By establishing themselves in foreign markets, these developing countries were able to overcome domestic credit ceilings and access cheaper foreign financing. These actions also enable the borrowing country to lessen or prevent the overwhelming panic that may occur if their domestic or foreign reserves became depleted. Even in a porous economic climate such as today, securitization of future flow receivables in emerging markets are performing well [2]. This is because the securitization of credit cards, tourism, trade, DPRs and other assets that were formerly not securitized are enabling developing countries to maintain their access to international capital markets, even in times of economic crisis.

\section{Standard Features of Securitization}

Securitization (See Figure 1) is the process by which pre-selected assets are pooled together to be repackaged and sold to investors as interest-bearing securities. This process originated in 1938 when U. S. government created 


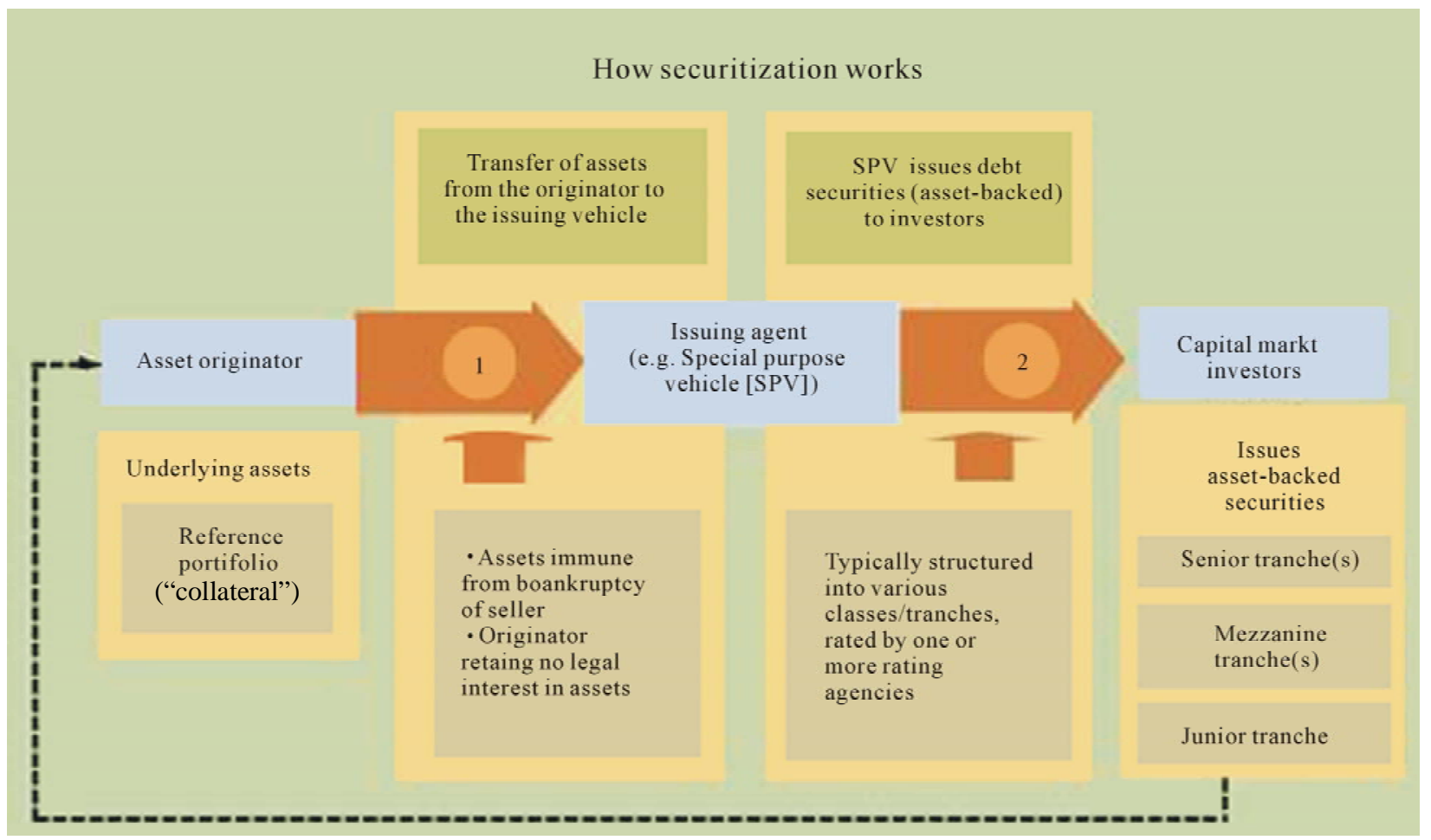

Figure 1. How securitization works [3].

Fannie Mae (and later, Freddie Mac in 1970). It pooled together home mortgages to be resold to other investors in order to remove credit-risk and interest rate-risk from banks; these large pools of home mortgages were sold as collective assets known as mortgage backed securities. It allowed for the post-war housing boom and growth of suburbia in the United States.

Later in the 1980s, other assets began to be securitized and the securitization market grew dramatically. Many financial institutions used securitization to transfer the credit risk of assets from their balance sheets to other financial institutions, such as hedge funds, insurance companies, and banks. Securitized assets are relatively cheap to hold because rating agencies have easier standards for them than the larger, non-securitized assets that they were originally taken from. Securitization also lowers the concentration of risk by spreading it across multiple entities [3].

A portfolio of securitizations is divided into sections, known as tranches, e.g., junior, mezzanine, senior, etc. Each tranche is sold individually due to their varying levels of risk. Junior has the most risk, mezzanine has the median level of risk, and senior tranches have the least amount of risk. Investment return, (which includes interest and principal repayment), and losses are distributed among the three tranches based on their risk levels. Senior tranches have the first choice of income generated from underlying assets due to their lowest level of risk; mezzanine gets next choice, and the junior receives the remainder of the income generated from underlying assets.

This concentrates portfolio losses in the junior tranches, which are the smallest in size. Thus, junior tranches also have the highest risk, and therefore the highest return to investors. Mezzanine tranches are the median in size and are the median in terms of returns to investors. Senior tranches have extremely low risk because of their low loss expectations. Investors often finance senior tranche purchases by borrowing from elsewhere.

Securitization originated as a way for financial institutions and corporations to find new sources of funding. It allowed banks to move assets off of their balance sheets or borrow against their assets to refinance their organization at a fair market rate. It also reduced their borrowing costs and in the case of banks, it lowered their minimum regulatory capital requirements [3]. Any asset that supports a stable cash flow can be placed into a reference portfolio and sold as securitized debt, which is why securitization has become so popular and has spread to smaller and emerging markets in recent years. In addition to mortgages, securities can be backed by individual lending agreements, home equity loans, consumer credit, small business loans, corporate loans, sovereign loans, project finance, lease receivables, and less/trade receivables. These securities are known as "asset backed securitizations" or "ABS.” Additionally, a variant is a collat- 
eralized debt obligation or "CDO" which uses the same process as ABS, but includes a larger and more diverse set of assets.

A major reason for the reduction in costs is because the assets are detached from the originator's balance sheet and credit rating, thus allowing the issuers of the assets to finance the purchase of the assets more cheaply than if they were not securitized. Securitization does not inflate a company's liabilities as conventional debt does. Instead, securitization produces funds for future investment without balance sheet growth. Through the securitization process, investors are able to quickly adjust their portfolios in response to changes in transactions costs, preferences, and market volatility.

Occasionally, securities are not sold directly from the originator to the issuer, which is called "true sale securitization." Instead, the originator sells only the credit risk associated with the asset without the transfer of its legal title; this is called "synthetic securitization." Synthetic securitization enables the issuers to exploit price differences between the acquired (and often illiquid), assets and the price investors are willing to pay for them if they are diversified in a larger pool of assets [3].

\section{Mechanics of Future-Flow Securitization}

First (See Figure 2), an established firm/country receiving the exported foreign funds, those to be used as future-flow receivables, has the foreign funds converted to their sovereign currency, in order to raise more funds in the same or other markets. Second, the "trustworthy" firm/country receiving the future-flow receivables establishes an "SPV", (Special Purpose Entity/Vehicle; also know as an "SPE/V"), in a tax neutral location outside the foreign country where the firm/country interested in receiving loan(s) is located. Third, the lending firm/country sells its current and future export receivables to the SPV for a lump sum payment; or the lending firm/country agrees to give the receivables to the SPV as security for a different loan from the SPV. Occasionally, the original lending firm/country, who also established the SPV, inherits liability by agreeing to repurchase the receivables from the SPV under unique pre-determined circumstances.

Next, the SPV funds the original loan/purchase price by issuing securities backed by its right to receive the existing and future-flow receivables. During a revolving period, the developing country acquiring the export receivables pays the SPV by putting their payment in the SPV's personal, independent, offshore bank accounts. The SPV uses the received payment to pay their own scheduled interest and principal payments on the securities exchanged and any other transaction costs; the re- maining cash from the original payment to the SPV is given back to the original payee country. Once the revolving period expires or is completed, all of the cash from the original payment to the SPV for the future-flow receivables is used to pay the interest and principal on the securities until they have been paid in full.

The most desirable attribute of future flow securitizations is that they allow firm/countries with external foreign currency debt ratings less than investment grade to obtain outside funding from international capital markets at more favorable rates. They can then issue securities with a higher foreign currency debt rating, using funds borrowed from a more credible source than themselves. This action allows the borrowing countries to bypass the "sovereign ceiling" because they can issue securities that are rated more highly than their native country's external foreign currency debt rating, which allows the borrowing country to gain access to higher quantity and quality international markets.

\section{Securitization Types and Requirements}

There are certain requirements for the types of receivables that can be used to support a future flow securitization: First, the receivables must be denominated in currency that is the same as the currency of the borrowing country. Second, the receivables must be indebted to creditworthy entities that are investment-grade rated which are not situated within the borrowing country's borders. Third, the receivables must be liquid outside of the borrowing country. Some examples of the types of receivables that have been used in recent future flow securitizations are US currency receivables owed to an Asian airline company by a credit card company for the purchase of airline tickets by credit card; and US currency receivables owed to an emerging market telecom company by international long distance telecom carriers for international long distance telephone calls.

Diversified Payment Rights, "DPRs," are securitizations based on funds already flowing through the banking system, e.g., export payments, ex-patriot workers sending money home, etc. DPRs receive higher credit ratings, on average, compared to bonds because their future flow receivables are being received from offshore obligors, the repayment is made directly by the [offshore] SPV to the investor. In addition, the higher investment grade ratings given to DPRs make them more attractive to a larger audience of investors, (e.g. insurance companies that will not purchase sub-investment grade investments). Lastly, the purchased receivables are included in the SPV assets and are not subject to the claims of any other creditors if bankruptcy were to occur [4]. 


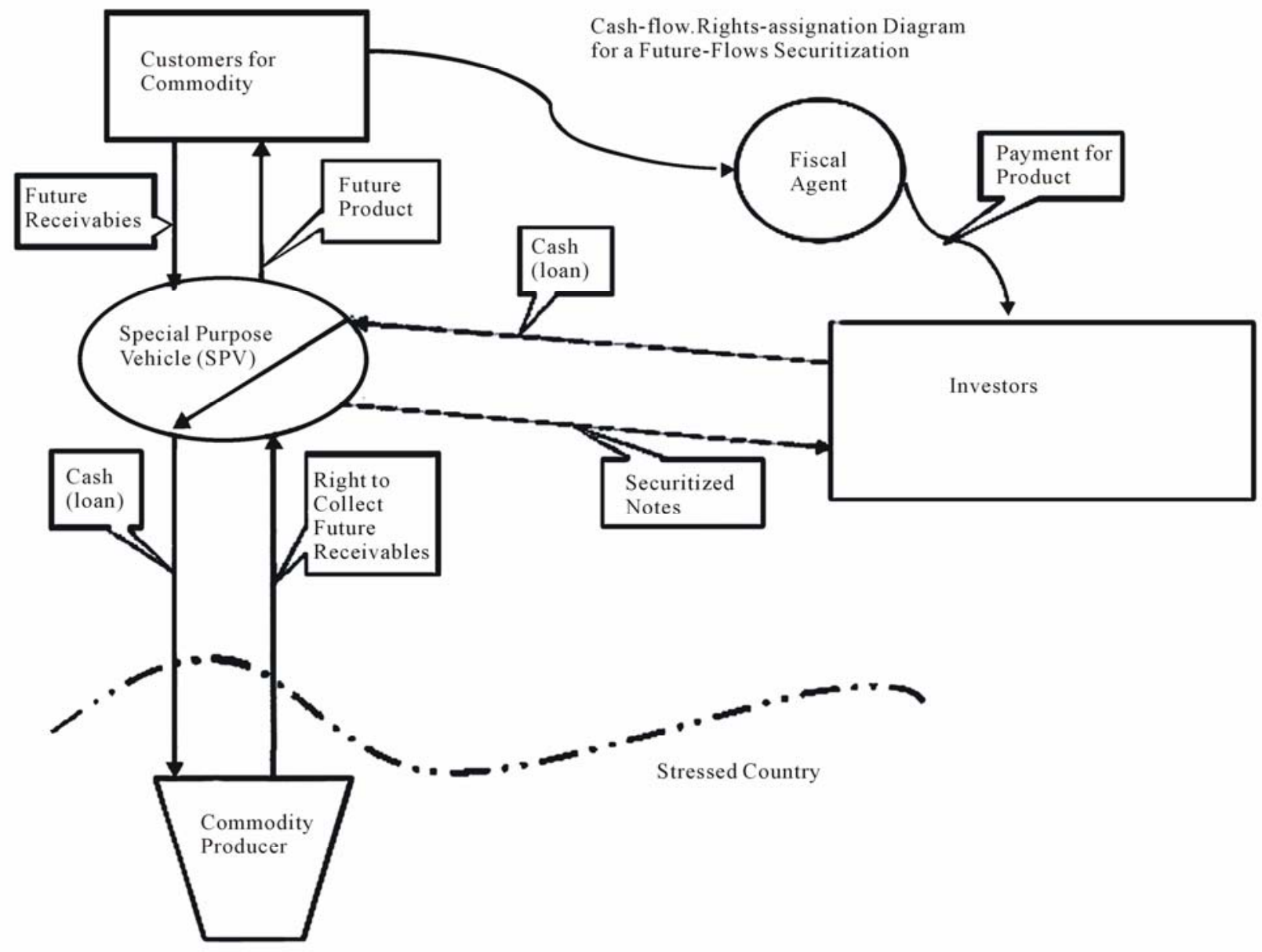

Figure 2. Cash-flows \& rights-assignations for typical future-flows securitization.

\section{Remittances}

DPRs also fall under the category of remittances. Remittances have become increasingly popular with both developed and developing countries. In 2005, global remittances were estimated at $\$ 225$ billion, which is twice as large formal development assistance flows from countries and governing bodies, and are the second largest flow of external financial transactions after direct foreign investments.

Remittance transactions play a significant role for developing countries by helping them to obtain the funds they need to develop and reduce sovereign poverty. Many of these developing countries do not have effective or efficient economic support systems for their citizens, and they have porous or nonexistent sovereign labor markets. Remittance flows from offshore/outside entities catalyze sovereign consumption and growth and thus make currency more mobile, and therefore available to more citizens.
Remittances are more consistent than other flows and are countercyclical, which help balance economic fluctuations due to exogenous factors. Remittances also promote economic stability, specifically in regards to foreign exchange rates. This helps to finance the developing country's trade deficit and spur national current account growth. Moreover, remittances strengthen a country's banking system by pumping more money into the private sector. The influx of new money supports expanded credit within the private sector and increases the deposit base which decreases the amount of excess demand in the sovereign loanable funds market.

\section{Remittance Examples}

For example, remittances are especially important for Central Asian economies. Due to the collapse of the Soviet Union and lack of natural resources, many of the Central Asian countries rely on remittances for stability and growth. Even though many citizens in Central Asian 
countries are literate and educated, the unemployment rates in these regions is strikingly high. Many citizens emigrate to find suitable employment and their home countries rely on employment as an exportable sovereign good for hire.

The nation of Kazakhstan also relies on remittances and compensation for emigration, although for different reasons. About 20\% of Kazakhstan's population emigrated due to ethnic or cultural friction in the 1990s (e.g. Jews, Germans, and Slavs). This left Kazakhstan at an extreme disadvantage, and in desperate need of remittances' to make up for the loss of developed human capital. Because Kazakhstan has been receiving outside remittances for the last decade, all of the following have increased within its borders: The number of borrowers, external sovereign lending, the disbursement of remittances, the sovereign credit quality of Kazakhstan, the share of total financial assets in financial sector, the total number of banking assets, the average size of loans, and the development of technology. All of these positive effects have lead to even more positive overall impacts of remittances in Kazakhstan: The continued development of the banking subsection, domestic securitization market, cross-border securitization market, and stability of the financial sector [5].

\section{Impact on Current Economic Recession}

As of late, securitization has become a larger player in commodities markets. The current global economic downturn combined with the recent credit crisis has increased the demand for the securitization of future flow receivables and DPRs. The ratings of sovereign debt have decreased causing the numbers of potential borrowers of future flow receivables and DPRs to grow even though their respective abilities to produce goods or the potential demand for these goods may have not changed. If a joint agreement is reached between the country producing the good, the customers for its good, and an off-shore/outside partner group which agrees to lend money to the producing country in exchange for the rights to the proceeds of the sale of the good to be sold to the producing country's customers, the off-shore/outside partner group may agree to lend guaranteed ("collaterized") funds to the producing country in exchange for the future cash flow produced by the sale of its goods to its customers. Although there is some risk involved, the risk decreases because the guaranteed cash flow comes from the outside creditworthy lending country, which in turn results in a lower price for credit.

This process has similarities with the sub-prime loan crisis that occurred within the last few years. Lenders would finance loans collateralized by homes and the fu- ture earnings of the borrower would pay for the interest on these loans. In the future flow securitization process, the future sale of commodities will pay for the interest on the loans. In both scenarios, the increasing price of the collateral reassures the investor of receiving his/her future payments from the borrower(s).

In the recent and still current economic downturn, securitization has become more involved in "CMOs" ("Collatealrized Mortgage Obligations"). In equity markets, a tremendous amount of trade comes from institutions and active traders balancing their market positions; connecting the two separate transactions is the fact that much of the trading in CMOs during the recent economic downturn has more to do with large and small market players adjusting their portfolios and less to do with confidence in the real estate market. Moreover, active market players have helped spur the growth of commodities markets from an estimated \$ 643 million in 1994, to \$ 5.2 billion in 2004, to an estimated $\$ 80$ billion at the beginning of 2010 [4].

\section{Risks and Regulations}

Although leveraged financing schemes are inherently risky, and thus ask for higher returns from the borrower to the lender, CMOs are especially dependent upon the default rate. Much along the same lines that overestimates by financial intermediaries and monetary government bodies about the incomes of home-owners weakened the CMO market and played a catalyzing role in current recession, there is a similar risk relating to commodities: Due to the necessity of looser financial restrictions when it comes to secondary markets, the value of commodities are skyrocketing, perhaps with negative future ramifications.

Even though contracts in commodity markets are normally private and require additional informational services to assess their quality and risk, it is plausible to compare the role CMOs played in the current financial crisis to the potential role commodities could play in prolonging this current economic crisis, or creating a new credit crunch in the future.

First off, the demand for commodities has been derived from the current economic downturn because commodity producers are searching for lenders due to the increased borrowing costs imposed by declining sovereign debt ratings. Additionally, lenders want to lock in yields above what can be obtained in more conventional money markets because they are more risk-averse now than possibly ever before. Lastly, the demand for most commodities can only increase. If the aforementioned theories hold true, which is seeming more and more likely as time goes by, the movement in commodities 
prices may actually be caused by, (NOT correlated to), a growing market in securitized products for their future cash flows. This movement in commodities prices makes their pricing mechanism even more complex to decipher, which makes the task of creating standards for securities across international markets that much more difficult.

Commodities are much more volatile than corporate bonds or real estate investments, which will naturally result in a greater danger of default, similar to the current mortgage downturn. This fact leads many educated people in the financial world to believe that these structured financial products are very sensitive to prices, which are dependent on default risk. The increased beta on these assets reflected an increase in systematic risk due to sectors such as real estate once the generous ratings were removed from some of the packaged securities. This same dilemma is likely to occur in the commodities market because of its greater volatility.

Additionally, commodities' prices are sensitive to exogenous factors such as political (monetary and fiscal policy), economic (money, capital, national, global markets), and geographical (natural disasters, tourism), and other unpredictable factors. Moreover, because commodities are used in numerous ways, simulation based on empirical evidence is more appropriate than creating a tangible and exact pricing model. Nonetheless, simulations are only worthwhile mechanisms if all of their parts fit together to make a puzzle as close to the real dilemma as possible.

\section{Agricultural Commodities}

Agricultural commodities are pivotal in the economic well-being in both developed and developing nations. Agricultural commodities are often a key economic export in developed nations, but inherently risky [volatile] commodity prices can greatly affect agricultural commodities. For example, if an exporting nation experiences a decrease in demand in conjunction with an unchanging production rate, it can experience a significant economic downturn. Even if production is decreased when demand initially decreases, the agricultural sector will be dealt a blow with job losses.

In comparison, certain agricultural commodities are inherently in demand. Corn is used to feed livestock and as natural fuel in the form of ethanol. Due to government programs across the world encouraging, (and occasionally subsidizing), domestic producers and consumers who are active producing ethanol in order to reduce fossil fuels and increasing alternative energy options and consumption, corn generally experiences high demand.

Continuing with the corn example, the increase in demand for corn can lead to other dilemmas. As corn prices rise due to increased derived demand for ethanol, farmers have less corn to feed their livestock with, and may have to sell off some of their livestock. However, it takes time to sell off livestock as farmers will search for the best buyers and negotiate for the highest prices. Thus, the price of meat can remain low for long periods of time because livestock buyers know that they have the upper hand in bargaining since farmers need to get rid of livestock in order to slow their losses. [6] As the supply of livestock decreases over time, the domestic and/or international price of meat may rise, causing underdeveloped nations and/or people with lower incomes to consume less protein and possibly decrease the quality of their health.

Higher grain prices have catalyzed higher prices for agricultural assets in equities markets. However, most investors do not want to get involved with future flow receivables, and invest in proxies instead, (such as fertilizer companies and tractors in reference to grain equities). The investment in proxies might artificially inflate their prices in the short run, and investors should research for other reasons why these prices may increase, decrease, or remain constant in the future.

When the harvests are completed early or on time, and the harvest's size and condition are close to predicted market values, it caps agricultural equities prices for the short term (few months at most).

Moreover, the U.S. dollar is currently weak compared to other international currencies, i.e., Euro or Yuan, making U.S. agricultural goods cheaper and raising the purchasing expectations of domestic grain harvesters and traders.

In the case of the Chinese Yuan, because China purchased so much U.S. debt as investments, the Yuan and U.S. dollar are connected. An increase [decrease] in Chinese interest rates would increase [decrease] the value of the Yuan and increase [decrease] the value of the U.S. dollar. A stronger dollar will lower demand for U.S. agricultural goods in international market places, which could lessen the amount of grain traded in exchanges. This is partly due to the fact that not all investors understand that agricultural goods are produced on farms under varying exogenous and endogenous conditions rather than controlled factory conditions such as processed products [6].

Nonetheless, underdeveloped nations frequently invest in agricultural infrastructure and innovation because of their available untapped natural resources or potential contributions to global markets if their societies are improved. The work on improving the purification system for Africa's water by multiple investors could have a major impact on the global economy in numerous ways and sectors. 
A diverse group of agricultural commodities are also traded in many exchanges around the world. Trading agricultural commodities strengthens their business and individual market by allowing farmers to lock in constant prices for the future. Without the trade of agricultural commodities, farmers would be more at risk for losing the value of their crops to unpredictable negative events, such as natural disasters [7].

\section{Summary}

The economic and financial applications potential of all non-standard securitizations is infinite. If it were possible to come up with a way to be able to make securitizations standard so they could be traded, bought, and sold in marketplaces across the globe, the current global economic crisis could be corrected, and possibly become an economic boom.

The number and type of assets that are able to be securitized have increased enormously in recent years, and can continue to do so if internationally accepted standards are created for securitizations.

However, due to exogenous factors such as different economic climates in different countries and regions of the world, language barriers, and different codes of moral and ethical conduct; as well as endogenous factors such as: Will the borrowing country receiving the money from the established lending country actually use the money for the same purposes that they promised to? (Moral Hazard quandary); does the borrowing country know enough about the established and more developed country lending them money to know if they are getting a fair deal or not? (Adverse Selection problem)

As soon as a solution to the standardizing of securiti- zations in one marketplace becomes reality, it will be much easier to create variations of this solution to other market places, and thus generate more business across the world - perhaps fuelling the next economic boom.

\section{References}

[1] C. Culp, L. Forrester and J. Paul, "Structured Financing Techniques in Oil \& Gas Project Finance: Future Flow Securitizations, Prepaids, Volumetric Production Payments, and Project Finance Collateralized Debt Obligations," Social Science Research Network, August 2009 http://www.rmcsinc.com/articles/CLCJPF.pdf

[2] S. Mohapatra, "How Remittance Securitizations Can Help Developing Countries during a Credit Crisis,” People Move, 27 August 2008 http://blogs.worldbank.org/peoplemove

[3] A. Jobst, "Back to Basics," Finance and Development, Vol. 45, No. 3, September 2008.

[4] L. Bernard and W. Semmler, "Boom-Bust Cycles: Leveraging, Complex Securities, and Asset Prices,” (working paper) September 2009.

[5] Asian Development Bank (“ADB”), Report and Recommendations of the President to the Board of Directors, Project Number 40941: July 2007.

[6] N. Schmidt, "Food Prices Spiraling Higher, Grains Feed Meat Prices,” The Market Oracle, October 2010. http://www.marketoracle.co.uk/Article23658.html http://www.wisegeek.com/what-are-agricultural-commod ities.htm

[7] “What Are Agricultural Commodities?” Wisegeek 2010. http://www.wisegeek.com/what-are-agricu-tural-commod ities.htm http://www.wisegeek.com/what-are-agricultural-commod ities.htm 